\title{
若年者に発生した異型脂肪腫の一例
}

熊本大学医学部整形外科
山 下 武 士・米 村 憲 輔
西 田 公 明・薬師寺 俊 剛
加 藤 悌 二・鬼 木 泰 成
高 木 克 公

\section{A Case of Atypical Lipoma in Childhood}

\author{
Takeshi Yamashita, Kensuke Yonemura, Kimiaki Nishida, Toshitake Yakushiji, \\ Teiji Kato, Yasunari Oniki and Katsumasa Takagi \\ Department of Orthopaedic Surgery, \\ Kumamoto University School of Medicine, Kumamoto, Japan
}

\begin{abstract}
We report a rare case of atypical lipoma in childhood. A 13 year-old boy had a 3-month history of the left thigh nodule. When he visited our hospital, the tumor was seen at the lateral aspect of the left thigh and was $7 \times 6 \mathrm{~cm}$ in size. Computed tomography showed a subcutaneous mass indicating low and iso density. Magnetic resonance imaging showed an abnormal shadow, indicating low and high signal intensity on T1 weighted images. Surgical excision of the tumor was performed. Microscopic examination of the tumor showed that the lesion composed of mature adipocytes with considerable variation in size and shape, containing many atypical spindle cells and pleomorphic giant cells. We believe that the clinicopathological feature fulfills the criteria of atypical lipoma. This type of tumor is considered a superficially located well-differentiated liposarcoma, and may recur locally, but has a minimal chance to metastasize.
\end{abstract}

Key words : Atypical lipoma (異型脂肪腫), pleomorphic lipoma (多形性脂肪腫), spindle cell lipoma (紡錐形脂肪腫), liposarcoma（脂肪肉腫）

\section{はじめに}

異型脂肪腫は中高年に好発する比較的まれな腫瘍で ある. 今回我々は, 若年者に発生した異型脂肪腫の一 例を経験したので報告する.

症例

症例 : 13 歳, 男性.

主訴 : 左大腿腫瘤.

現病歴 : 平成 9 月 3 月頃より左大腿の腫瘤に気づい

た．腫瘤は徐々に增大するため，同年 5 月近医を受診

し, 諸検查にて軟部腫瘍を疑われ当科を紹介された。
現症: 左大腿遠位外側に $7 \times 6 \mathrm{~cm}$ 大, 弾性硬の腫 瘤を触知した。腫脹, 熱感, 圧痛はなかった。また腫 瘤の可動性は良好であり, 皮唐及び下層の筋膜との瘉 着はなかった. その他入院時の血液検查では特に異常 を認めなかった。

画像所見 : 単純X線では皮下に腫瘍陰影を認めるも のの, その他の異常はみられなかった.

CT では fat density ないし iso density の境界明瞭

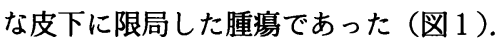

MRI では, T1 强調像で高信号を呈する脂肪腫の成 分と, $\mathrm{T} 1$ 強調像で低信号, $\mathrm{T} 2$ 強調像で高信号を示す 領域がみられた。造影 MRI では, T1 強調像で低信 
号を呈する部分に 軽度の増強効果を認めた（図 2 ）.

入院後経過：入院後施行した needle biopsy では 多形性脂肪腫, 紡錐形脂肪腫が考えられ, 平成 9 年 6 月手術を施行した．左大腿外側に約 $10 \mathrm{~cm}$ の皮切を加 え，下層の腸脛勒帯まで展開した。腫瘍と勒帯との癒 着はなく可動性は良好であったため, 筋膜直上で切除 した.

摘出した腫瘍は $6 \times 5 \times 3 \mathrm{~cm}$ で, 通常の脂肪腫よ りやや硬く, 割面は黄色を呈する脂肪腫の成分が大部 分であり，それを区画するように灰白色の線維成分が みられた。

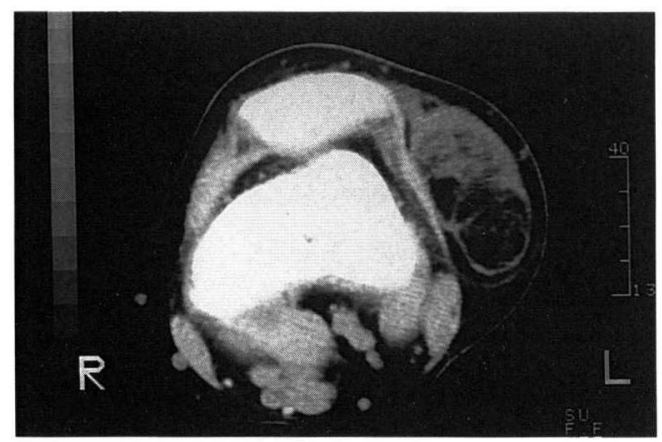

図1 CT 像. fat density の領域と iso density を示 す部分が混在した皮下に限局した腫瘤を認めた。
組織学的には, 膠原線維によって分葉化された成熟 脂肪細胞からなり, 線維芽細胞の増生した部分も見ら れた. MRIの T1 強調像で低信号を呈する部分では, 線維芽細胞の増生した領域が比較的多く, 腫大した核 や，2 ないし 4 個の核を持っ巨細胞，あるいは好酸性 の細胞質を持つ粘液腫様の細胞, さらに脂肪芽細胞が 散見された. 一方, MRI の T1 強調像で高信号を示 す部分では, 分葉構造がさらに明瞭となり, 膠原線維 自体も成熟していた，強拡では多少の大小不同はみら れるものの単房性の成熟脂肪細胞であり，核分裂像は 見られなかった（図3）.

以上の臨床経過, 組織所見より異型脂肪腫と診断し た. 現在術後 1 年で再発を認めず経過良好である.

考察

異型脂肪腫は Kindblom ら4)，および Evans ら が, 従来高分化型脂肪肉腫之診断されていたものの中 で，手術のみで治癒し転移をきたさない皮下発生の腫 瘍に対し命名したものである. 多形性脂肪腫, 紡錐形 脂肪腫も組織像が酷似しており, 異型脂肪腫とほぼ同 一腫瘍と考えてよいとする報告むあり，一部では混同 されて用いられている(1)3). しかし， Enzinger ら ${ }^{2)} に$ よれば, 多形性脂肪腫, 紡錐形脂肪腫は明らかに臨床 像が異なり，50 歳以上の男性で肩甲部，背部の皮下

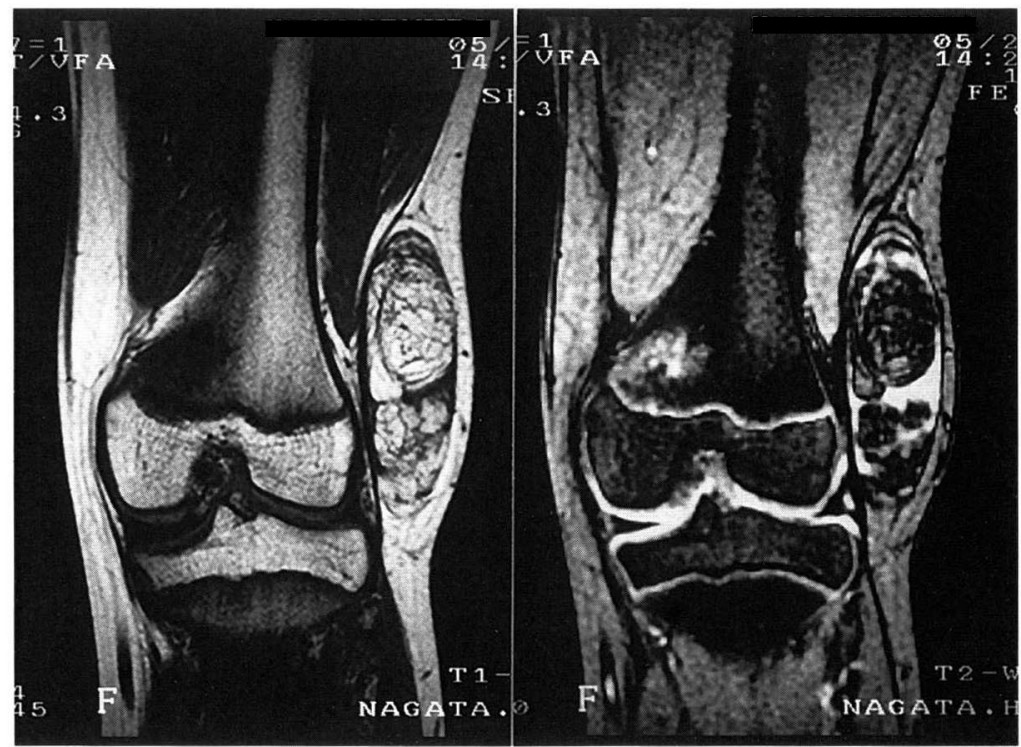

図 2 MRI 像. T1 強調像で高信号を呈する脂肪腫の成分と, T1 強調像で低信号, $\mathrm{T} 2$ 強調像で高信号を示す領域がみられた（右 T1 強調像, 左 T2 強調像). 


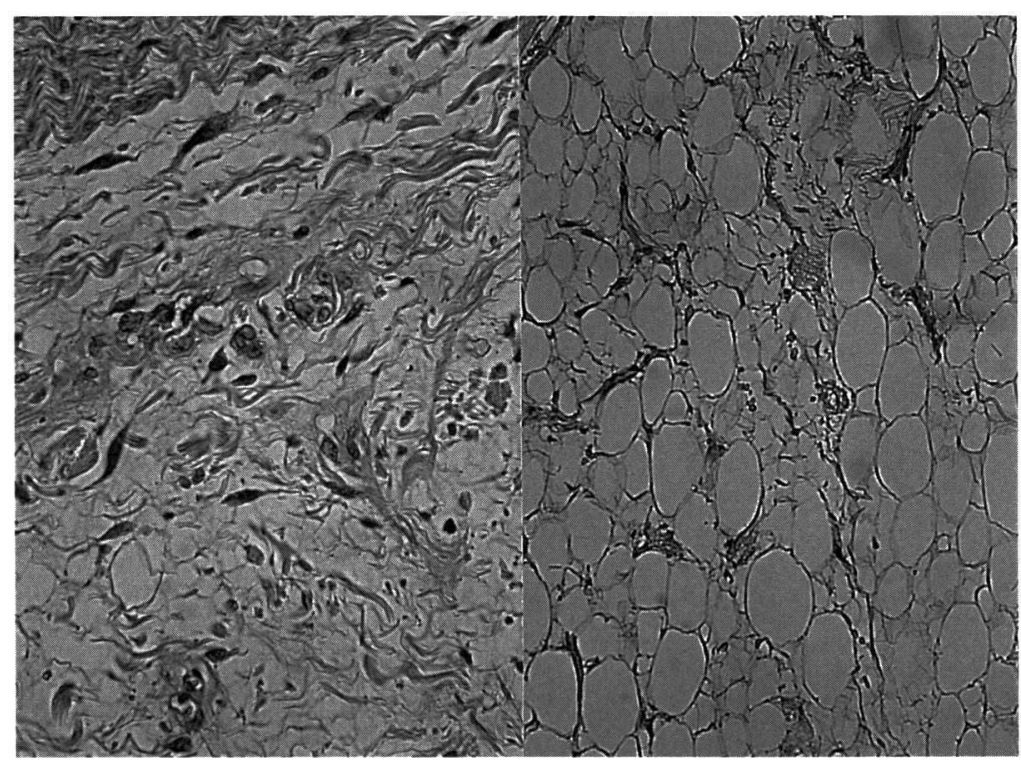

図 3 組織像. 線維芽細胞の増生した領域では, 異型性のある紡錐形細胞, 多核巨細 胞, 粘液腫様の細胞がみられ（右）, MRI の T1 強調像で高信号を示す部分は, 大小不同を伴う単房性脂肪細胞であった (左).

に発生するあのに限るべきで, 単純摘出であっても再 発や転移あるいは脱分化はなく, 良性脂肪腫群の一亜 型として疾患単位を明記し，区別している.

諸家の報告によれば, 異型脂肪腫の好発年齢は 40 歳以降であるとされており, 我々の渉猟しえた限りで 屯, 本症例の如く 10 代での発生は 57 例中 1 例のみで あった. したがって本症例は, 発生年齢の点で比較的 稀な症例であると思われる。 また発生部位に関しては, 後頸部, 背部, 肩甲部などが好発部位であり, 四肢発 生は比較的頻度が低いとされる。しかしこの中には多 形性脂肪腫, 紡錐形脂肪腫と思われる症例む含まれて いると考えられ, 発生部位の点で本症例が非典型例で あるかについては明らかではない。

組織学的鑑別診断としては, 脂肪芽細胞腫, 巨細胞 性線維腫, 多形性脂肪腫, 紡錐形脂肪腫などの良性腫 瘍, 低悪性度の脂肪肉腫などが挙げられる. 本症例の 場合, 皮下発生で比較的短期間の間に腫瘍が増大して おり, 前述した組織像を総合的に考虑し, 異型脂肪腫 と診断した。

治療に関して Enzinger ら ${ }^{2)}$ は，本症例のような皮 下発生のいわゆる異型脂肪腫に対しては, 辺縁切除よ
りやや広い切除縁での切除で十分であると述べている. しかし本症例のように若年発生は稀であり, 今後も注 意深い経過観察が必要であると考えている.

\section{結語}

今回我々は, 若年者に発生した異型脂肪腫の一例を 経験したので, 若干の文献的考察を加えて報告した.

\section{参 考 文 献}

1) Azumi, N. et al. : Atypical and malignant neoplasms showing lipomatous differentiation. A study of 111 cases. Am. J. Surg. Pathol., 11(3) : 161-183, 1987.

2) Enzinger, F. M. and Weiss, S. W. : Atypical lipoma and well-differentiated liposarcoma. In Soft Tissue Tumor. 3rd ed., pp.450-451. St. Louis, Mosby, 1995.

3) Evans, H. L., Soule, E. H. and Winkelmann, R. K. : Atypical lipoma, atypical intramuscular lipoma, and well differentiated retroperitoneal liposarcoma. A reappraisal of 30 cases formerly classified as well differentiated liposarcoma. Cancer, 43 : 574-584, 1979.

4) Kindblom, L. G., Angervall, L. and Fassina, A. S. : Atypical lipoma. Acta Pathol. Microbiol. Scand., 90A : $27-36,1982$. 